\title{
Full Field Digital Mammography (FFDM) versus CMOS Technology, Specimen Radiography System (SRS) and Tomosynthesis (DBT) - Which System Can Optimise Surgical Therapy?
}

\author{
Digitale Vollfeldmammografie (FFDM), CMOS-Technologie, Specimen Radiography System (SRS) \\ versus Tomosynthese (DBT) - welches System optimiert die operative Therapie?
}

Authors

Affiliations
R. Schulz-Wendtland ', G. Dilbat ${ }^{2}$, M. Bani' ${ }^{3}$, P. A. Fasching ${ }^{3}$, K. Heusinger ${ }^{3}$, M. P. Lux ${ }^{3}$, C. R. Loehberg ${ }^{3}$, B. Brehm ${ }^{1}$, M. Hammon ${ }^{1}$, M. Saake ${ }^{1}$, P. Dankerl ${ }^{1}$, S. M. Jud ${ }^{3}$, C. Rauh ${ }^{3}$, C. M. Bayer ${ }^{3}$, M. W. Beckmann ${ }^{3}$, M. Uder ${ }^{4}$, M. Meier-Meitinger ${ }^{1}$

The affiliations are listed at the end of the article

\author{
Key words \\ - Breast \\ - mammography \\ - breast cancer \\ - breast malignancy \\ Schlüsselwörter \\ - Mamma \\ - Mammografie \\ - Mammakarzinom \\ - Mammamalignom
}

received 12.3.2013 revised 16.4.2013 accepted 16.4.2013

Bibliography

DOI http://dx.doi.org/

10.1055/s-0032-1328600

Geburtsh Frauenheilk 2013; 73:

422-427 @ Georg Thieme

Verlag KG Stuttgart · New York . ISSN 0016-5751

\section{Correspondence}

Prof. Rüdiger Schulz-

Wendtland, Dr. med.

Radiologisches Institut des Universitätsklinikums Erlangen

Gynäkologische Radiologie Universitätsstraße 21-23 91054 Erlangen

ruediger.schulz-wendtland@ uk-erlangen.de

\section{Abstract \\ $\nabla$}

Aim: This prospective clinical study aimed to evaluate whether it would be possible to reduce the rate of re-excisions using CMOS technology, a specimen radiography system (SRS) or digital breast tomosynthesis (DBT) compared to a conventional full field digital mammography (FFDM) system.

Material and Method: Between 12/2012 and 2/ 201350 patients were diagnosed with invasive breast cancer (BI-RADS ${ }^{\mathrm{TM}}$ 5). After histological verification, all patients underwent breast-conserving therapy with intraoperative imaging using 4 different systems and differing magnifications: 1. Inspiration ${ }^{\mathrm{TM}}$ (Siemens, Erlangen, Germany), amorphous selenium, tungsten source, focus $0.1 \mathrm{~mm}$, resolution $85 \mu \mathrm{m}$ pixel pitch, $8 \mathrm{lp} /$ $\mathrm{mm}$; 2. BioVision ${ }^{\mathrm{TM}}$ (Bioptics, Tucson, AZ, USA), CMOS technology, photodiode array, flat panel, tungsten source, focus 0.05 , resolution $50 \mu \mathrm{m}$ pixel pitch, $12 \mathrm{lp} / \mathrm{mm}$; 3 . the Trident ${ }^{\mathrm{TM}}$ specimen radiography system (SRS) (Hologic, Bedford, MA, USA), amorphous selenium, tungsten source, focus 0.05 , resolution $70 \mu \mathrm{m}$ pixel pitch, $7.1 \mathrm{lp} / \mathrm{mm}$; 4. tomosynthesis (Siemens, Erlangen, Germany), amorphous selenium, tungsten source, focus $0.1 \mathrm{~mm}$, resolution $85 \mu \mathrm{m}$ pixel pitch, $8 \mathrm{lp} / \mathrm{mm}$, angular range 50 degrees, 25 projections, scan time $>20$ s, geometry: uniform scanning, reconstruction: filtered back projection. The 600 radiographs were prospectively shown to 3 radiologists.

Results: Of the 50 patients with histologically proven breast cancer (BI-RADS ${ }^{\mathrm{TM}}$ 6), 39 patients required no further surgical therapy (re-excision) after breast-conserving surgery. A retrospective analysis $(n=11)$ showed a significant $(p<0.05)$ increase of sensitivity with the BioVision ${ }^{\mathrm{TM}}$, the Trident $^{\mathrm{TM}}$ and tomosynthesis compared to the Inspiration ${ }^{\mathrm{TM}}$ at a magnification of $1.0: 2.0$ or $1.0: 1.0$ (tomosynthesis) $(2.6,3.3$ or $3.6 \%)$, i.e. re-

\section{Zusammenfassung \\ $\nabla$}

Ziel: Prospektive Untersuchung, ob mit Hilfe der CMOS-Technologie, dem Specimen Radiography System bzw. der digitalen Brusttomosynthese (DBT) im Vergleich mit einem herkömmlichen FFDM-System eine Senkung der Rate an Reexzisionen möglich ist.

Material und Methode: In der Zeit von 12/2012 bis 2/2013 wurde bei 50 Patientinnen ein invasives Mammakarzinom (BI-RADSTM 5) diagnostiziert. Nach histologischer Sicherung erfolgte die brusterhaltende Therapie mit intraoperativem Präparateradiogramm mit 4 unterschiedlichen Systemen und Vergrößerungen: 1 . Inspiration ${ }^{\mathrm{TM}}$ (Siemens, Erlangen, Deutschland), amorphes Selen, W-Anode, Fokus $0,1 \mathrm{~mm}$, Ortsauflösung $85 \mu \mathrm{m}$ Pixelpitch, 8 Lp/mm. 2. BioVision ${ }^{\mathrm{TM}}$ (Bioptics, Tucson, AZ, USA), CMOS-Technologie, Photodioden Array, Flat Panel, W-Anode, Fokus 0,05, Ortsauflösung $50 \mu \mathrm{m}$ Pixelpitch, $12 \mathrm{Lp} / \mathrm{mm}$. 3. Trident $^{\mathrm{TM}}$ (Hologic, Bedford, MA, USA), Specimen Radiography System (SRS System), amorphes Selen, W-Anode, Fokus 0,05, Ortsauflösung $70 \mu \mathrm{m}$ Pixelpitch, 7,1 Lp/mm. 4. Tomosynthese (Siemens, Erlangen, Deutschland), amorphes Selen, W-Anode, Fokus $0,1 \mathrm{~mm}$, Ortsauflösung $85 \mu \mathrm{m}$ Pixelpitch, $8 \mathrm{Lp} / \mathrm{mm}$, Winkelbereich $50 \mathrm{Grad}, 25$ Projektionen, Scandauer $>20$ s, Geometrie: gleichförmige Abtastung, Rekonstruktion: gefilterte Rückprojektion. Die jeweils 600 Präparateradiogramme wurden prospektiv 3 Radiologen auf einem Befundungsmonitor präsentiert.

Ergebnisse: Bei den 50 Patientinnen mit histologisch gesichertem Mammakarzinom (BIRADS $^{\text {TM }}$ 6) war bei 39 Patientinnen nach erfolgter brusterhaltender Therapie keine weitere operative Therapie (Reexzision) indiziert. Die retrospektive Analyse $(n=11)$ ergab eine signifikante $(\mathrm{p}<0,05)$ Steigerung der Sensitivität des BioVision $^{\mathrm{TM}}{ }_{-}$, des Trident ${ }^{\mathrm{TM}}$-Systems und der Tomosynthese gegenüber dem Inspiration ${ }^{\mathrm{TM}}$ bei einer 
excision would not have been necessary in 2, 3 or 4 patients, respectively, compared to findings obtained with a standard magnification of $1.0: 1.0$.

Conclusion: The sensitivity of the BioVision ${ }^{\mathrm{TM}}$, the Trident ${ }^{\mathrm{TM}}$ and tomosynthesis was significantly $(\mathrm{p}<0.05)$ higher and the rate of re-excisions was reduced compared to FFDM using a conventional detector at a magnification of 2.0 but without zooming.
Vergrößerung von 1,0:2,0 bzw. 1,0:1,0 (Tomosynthese) (2,6, 3,3 bzw. 3,6\%) d.h. eine Reexzision wäre bei 2, 3 bzw. 4 Patientinnen nicht notwendig gewesen im Vergleich zur Standardvergrößerung 1,0:1,0.

Schlussfolgerung: Sowohl der Einsatz der PräparateradiografieSysteme BioVision ${ }^{\mathrm{TM}}$ und Trident ${ }^{\mathrm{TM}}$, aber auch die Tomosynthese zur Präparateradiografie erreichen eine signifikant $(\mathrm{p}<0,05)$ bessere Sensitivität und Reduzierung der Reexzisionsrate im Vergleich zu einem FFDM-System mit herkömmlichem Detektor unter der Voraussetzung einer reellen Vergrößerung mit dem Faktor 2,0, jedoch keinem Zooming.

\section{Introduction}

$\nabla$

The risk of a woman developing breast cancer at some stage in her life is approximately $10 \%$. This makes breast cancer the most common malignant growth in women and the most common cause of death for women between the ages of 35 and 55. In Germany, 55000 women develop breast cancer every year and 20000 die of it. The individual prognosis for patients with breast cancer depends on the extent of micrometastasis and spread of disease at the time of diagnosis and therapy [1-7].

Both the European Guidelines and the S3 Guidelines state that at least $70 \%$ of all malignant breast lesions (BI-RADS ${ }^{\text {TM }} 5$ ) should be histologically verified preoperatively - the target figure is $90 \%$ [8-11]. The thinking behind this is that only a single surgical intervention will be necessary after a detailed preoperative workup of a lesion diagnosed as a malignant process. In addition, all nonpalpable breast lesions need to be marked (e.g. placement of a guide wire) prior to surgery [8-11].

Intraoperative radiography is the method of choice to assess the completeness of resection. Proposed approaches include transporting a resected specimen in a suitable container from the operating room to the radiology department for direct radiological examination [8-11] or, better yet, carrying out digital radiography intraoperatively directly in the operating room (2 planes). The surgeon and the pathologist can then either view the digital radiographs on film (analog/digital) or, more efficiently, via PACS. In the literature, the re-excision rate for breast cancer after primary breast-conserving therapy (BCT) to treat breast cancer previously verified histologically (histologically B5 and therefore BIRADS $^{\mathrm{TM}} 6$ ) is between 10 and $57 \%$, depending on the defined safety margin $[12,13]$.

The aim of our prospective study was to evaluate whether the reexcision rate after histologically verified invasive breast cancer and subsequent breast-conserving therapy with wire localization could be reduced using CMOS technology (BioVision ${ }^{\mathrm{TM}}$; Bioptics, Tucson, AZ, USA), the Trident ${ }^{\mathrm{TM}}$ specimen radiography system (SRS) (Hologic, Bedford, MA, USA) and tomosynthesis (Siemens) compared to a conventional full field digital mammography system (Inspiration ${ }^{\mathrm{TM}}$, Siemens [standard]), using different magnifications.

\section{Material and Methods \\ $\nabla$}

Between 12/2012 and 2/2013 a total of 50 patients were diag-

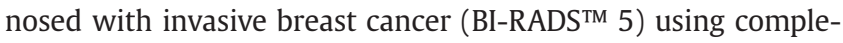
mentary diagnostics (clinical examination, mammography, sonography, MRT). Patient age ranged between 21 and 84 years (mean: 62 years). Lesion sizes ranged from 4 to $17 \mathrm{~mm}$ (median:
$13 \mathrm{~mm}$ ), depending on the imaging method used. In accordance with the European Guidelines and the S3 Guidelines [8-11] ultrasound-guided punch biopsy or stereotactic vacuum-assisted biopsy was done preoperatively in all patients with histological findings classified as B5, which were then diagnosed as BIRADS $^{\text {TM }} 6$. As none of the cases had multifocal or multicentric lesions and the maximum diameter was less than $2.0 \mathrm{~cm}$, in accordance with the S3 Guidelines none of the patients underwent primary neoadjuvant chemotherapy $[10,11]$.

After histological classification of the lesion as B5 (diagnostic evaluation: BI-RADS ${ }^{\mathrm{TM}}$ 6), all patients had ultrasound-guided or stereotactic wire localization preoperatively, depending on the primary method used for histological verification of the findings [8-11]. The lesions could be successfully localized at the first attempt in 46 patients, after the second attempt in 3 patients and after the third attempt in 1 patient. Breast-conserving therapy with sentinel lymph node biopsy (identified using patent blue and technetium-99m) was performed. This resected specimen was suture marked (for orientation, 3 planes). The specimen was examined radiologically without compression with the wire still left in place [14] using 4 different systems (Inspiration ${ }^{\mathrm{TM}}$ [System 1]: 2 planes, standard; BioVision ${ }^{\mathrm{TM}}$ [System 2]: 2 planes; Trident $^{\mathrm{TM}}$ [System 3]: 2 planes; tomosynthesis [System 4]: 1 plane) and AEC (Automatic Exposure Control) (๑ Table 1):

1. Inspiration ${ }^{\mathrm{TM}}$ (Siemens, Erlangen, Germany), amorphous selenium, tungsten source, focus $0.1 \mathrm{~mm}$, resolution $85 \mu \mathrm{m}$ pixel pitch, $8 \mathrm{lp} / \mathrm{mm}$.

2. BioVision ${ }^{\mathrm{TM}}$ (Bioptics, Tucson, AZ, USA), CMOS technology, photodiode array, flat panel, tungsten source, focus 0.05 , resolution $50 \mu \mathrm{m}$ pixel pitch, $12 \mathrm{lp} / \mathrm{mm}$.

3. Trident ${ }^{\mathrm{TM}}$ (Hologic, Bedford, MA, USA), a specimen radiography system (SRS), amorphous selenium, tungsten source, focus 0.05 , resolution $70 \mu \mathrm{m}$ pixel pitch, $7.1 \mathrm{lp} / \mathrm{mm}$.

4. Tomosynthesis (Siemens, Erlangen, Germany), amorphous selenium, tungsten source, focus $0.1 \mathrm{~mm}$, resolution $85 \mu \mathrm{m}$ pixel pitch, $8 \mathrm{lp} / \mathrm{mm}$, angular range 50 degrees, 25 projections, scan time $>20$ s, geometry: uniform scanning, reconstruction: filtered back projection.

BioVision $^{\mathrm{TM}}$ (CMOS technology, System 2) and Trident ${ }^{\mathrm{TM}}$ (specimen radiography system [SRS], System 3) are digital systems used exclusively for intraoperative radiography.

On completion of the invasive procedure, all specimens were $\mathrm{x}$ rayed again without compression according to the capabilities of the different system systems, using the following magnifications:

- $1.0: 1.0 ; 1.0: 1.5 ; 1.0: 1.8$ with $26-28 \mathrm{kV}$ (Inspiration ${ }^{\mathrm{TM}}$ )

- $1.0: 1.0 ; 1.0: 1.4 ; 1.0: 2.0$ with $26-28 \mathrm{kV}$ (BioVision $\left.^{\mathrm{TM}}\right)$

- $1.0: 1.0 ; 1.0: 1.5 ; 1.0: 2.0$ with $26-28 \mathrm{kV}$ (Trident $\left.{ }^{\mathrm{TM}}\right)$

- $1.0: 1.0 ; 1.0: 1.0 ; 1.0: 1.0$ with $26-28 \mathrm{kV}$ (tomosynthesis) 
Table 1 Basic technical characteristics of the different systems used for intraoperative radiography (Inspiration ${ }^{\mathrm{TM}}$ [System No. 1]; BioVision ${ }^{\mathrm{TM}}$ [System No. 2]; Trident $^{\mathrm{TM}}$ [System No. 3]); tomosynthesis (System No. 4) additionally offers the possibility to view projection images in dynamic cine mode using an angular range of 50 degrees for 25 projections, a scan time of $>20$ s, a uniform scanning geometry and filtered back projection for reconstruction.

\begin{tabular}{|c|c|c|c|c|}
\hline & $\begin{array}{l}\text { System No. 1: } \\
\text { Inspiration }^{\mathrm{TM}}\end{array}$ & $\begin{array}{l}\text { System No. 2: } \\
\text { BioVision }^{\mathrm{TM}}\end{array}$ & $\begin{array}{l}\text { System No. 3: } \\
\text { Trident }^{\mathrm{TM}}\end{array}$ & $\begin{array}{l}\text { System No. 4: } \\
\text { tomosynthesis }\end{array}$ \\
\hline Manufacturer & Siemens & Bioptics & Hologic & Siemens \\
\hline Anode & molybdenum, tungsten & tungsten & tungsten & molybdenum, rhodium \\
\hline Filter & molybdenum, rhodium & beryllium & beryllium & molybdenum, rhodium \\
\hline Anti-scatter radiation grid & linear & no & no & linear \\
\hline Conversion material & $\begin{array}{l}\text { semiconductor } \\
\text { a-Se }\end{array}$ & $\begin{array}{l}\text { photon conversion material: } \\
\text { Gd202S: Tb (terbium-doped gado- } \\
\text { linium oxysulfide) phosphorous }\end{array}$ & $\begin{array}{l}\text { TFT-based direct capture } \\
\text { technology }\end{array}$ & $\begin{array}{l}\text { semiconductor } \\
\text { a-Se }\end{array}$ \\
\hline Selection process & thin-film transistors & progressive line-scan selection & thin-film transistors & thin-film transistors \\
\hline Pixel size & $85 \mu \mathrm{m}$ & $50 \mu \mathrm{m}$ & $70 \mu \mathrm{m}$ & $85 \mu \mathrm{m}$ \\
\hline Resolution (Nyquist frequency) & $8 \mathrm{lp} / \mathrm{mm}$ & $12 \mathrm{lp} / \mathrm{mm}$ & $7.1 \mathrm{lp} / \mathrm{mm}$ & $8 \mathrm{lp} / \mathrm{mm}$ \\
\hline Field size & $24 \times 30 \mathrm{~cm}^{2}$ & $14 \times 12 \mathrm{~cm}^{2}$ & $14 \times 12 \mathrm{~cm}^{2}$ & $24 \times 30 \mathrm{~cm}^{2}$ \\
\hline
\end{tabular}

The radiographs (digital full field mammography: Inspiration ${ }^{\mathrm{TM}}$ [2 planes $]$ = standard; BioVision ${ }^{\mathrm{TM}}[2$ planes $]$; Trident $^{\mathrm{TM}}[2$ planes]; tomosynthesis [1 plane, 25 projections, dynamic cine mode]) obtained from a total of 50 specimens resected during breast-conserving surgery were prospectively shown intraoperatively on a diagnostic monitor to 3 radiologists with varying degrees of experience of digital mammography, i.e. radiologists were shown a total of 600 specimen radiographs. The diagnostic findings (lesion present with sufficient margin of safety $[1.0 \mathrm{~cm}]$ on all 3 planes of the specimen radiograph [2 planes or 25 projections] or not) $[10,11]$ was then correlated with the final comprehensive histological diagnosis. All of the radiologists knew that all specimen radiographs showed a malignancy.

\section{Results}

Of the 50 patients with histologically proven breast cancer (BIRADS $^{\text {TM }} 6$ ), 39 patients required no further surgical intervention (re-excision) after breast-conserving therapy, as confirmed directly by radiographs made (intraoperatively) during the primary surgical intervention (Inspiration ${ }^{\mathrm{TM}}, 2$ planes, magnification $1.0: 1.0$, System 1 [standard]).

The final histopathologic diagnosis for 11 operated patients (reexcision) showed incomplete resection during primary surgery in 2 patients and a safety margin $<1.0 \mathrm{~cm}$ in 3 patients, i.e. no residual tumor detectable. This means that, based on the final his-

Table 2 Sensitivity and specificity of the 3 systems (System No. 1: Inspiration ${ }^{\mathrm{TM}}$, System No. 2: BioVision ${ }^{\mathrm{TM}}$, System No. 3: Trident ${ }^{\mathrm{TM}}$, and System No. 4: tomosynthesis) as determined by 3 different radiologists who undertook a prospective evaluation of a total of 600 specimen radiographs/projection images (cine mode) of 50 patients with a malignancy (50 malignant lesions in total).

\begin{tabular}{|c|c|c|c|c|c|c|c|c|}
\hline & \multicolumn{4}{|c|}{ Sensitivity (\%) } & \multicolumn{4}{|c|}{ Specificity (\%) } \\
\hline $\begin{array}{l}\text { Magnification } \\
1.0: 1.0 \text { (No. } 1 \text { ) } \\
1.0: 1.0 \text { (No. } 2 \text { ) } \\
1.0: 1.0 \text { (No. } 3 \text { ) } \\
1.0: 1.0 \text { (No. } 4 \text { ) }\end{array}$ & $\begin{array}{l}\text { System } \\
\text { No. 1: } \\
\text { Inspira- } \\
\text { tion } \\
(85 \mu \mathrm{m})\end{array}$ & $\begin{array}{l}\text { System } \\
\text { No. 2: } \\
\text { BioVision }^{\mathrm{TM}} \\
(50 \mu \mathrm{m})\end{array}$ & $\begin{array}{l}\text { System } \\
\text { No. 3: } \\
\text { Trident }^{\mathrm{TM}} \\
(70 \mu \mathrm{m})\end{array}$ & $\begin{array}{l}\text { System } \\
\text { No. 4: tomo- } \\
\text { synthesis } \\
\text { (85 } \mu \mathrm{m})\end{array}$ & $\begin{array}{l}\text { System } \\
\text { No. 1: } \\
\text { Inspira- } \\
\text { tion }^{\mathrm{TM}} \\
(85 \mu \mathrm{m})\end{array}$ & $\begin{array}{l}\text { System } \\
\text { No. 2: } \\
\text { BioVision }^{\mathrm{TM}} \\
(50 \mu \mathrm{m})\end{array}$ & $\begin{array}{l}\text { System } \\
\text { No. 3: } \\
\text { Trident }^{\mathrm{TM}} \\
(70 \mu \mathrm{m})\end{array}$ & $\begin{array}{l}\text { System } \\
\text { No. 4: tomo- } \\
\text { synthesis } \\
(85 \mu \mathrm{m})\end{array}$ \\
\hline Radiologist 1 & 78.0 & 79.0 & 79.0 & 87.0 & 100.0 & 100.0 & 100.0 & 100.0 \\
\hline Radiologist 2 & 79.0 & 78.0 & 78.0 & 87.0 & 100.0 & 100.0 & 100.0 & 100.0 \\
\hline Radiologist 3 & 78.0 & 79.0 & 78.0 & 86.0 & 100.0 & 100.0 & 100.0 & 100.0 \\
\hline Mean & 78.3 & 78.6 & 78.3 & 86.6 & 100.0 & 100.0 & 100.0 & 100.0 \\
\hline $\begin{array}{l}\text { Magnification } \\
1.0: 1.5 \text { (No. } 1 \text { ) } \\
1.0: 1.4 \text { (No. } 2 \text { ) } \\
1.0: 1.5 \text { (No. } 3 \text { ) } \\
1.0: 1.0 \text { (No. } 4 \text { ) }\end{array}$ & $\begin{array}{l}\text { System } \\
\text { No. 1: } \\
\text { Inspira- } \\
\text { tion }^{\mathrm{TM}} \\
(85 \mu \mathrm{m})\end{array}$ & $\begin{array}{l}\text { System } \\
\text { No. 2: } \\
\text { BioVision }^{\mathrm{TM}} \\
(50 \mu \mathrm{m})\end{array}$ & $\begin{array}{l}\text { System } \\
\text { No. 3: } \\
\text { Trident } \\
(70 \mu \mathrm{m})\end{array}$ & $\begin{array}{l}\text { System } \\
\text { No. 4: tomo- } \\
\text { synthesis } \\
(85 \mu \mathrm{m})\end{array}$ & $\begin{array}{l}\text { System } \\
\text { No. 1: } \\
\text { Inspira- } \\
\text { tion }^{\mathrm{TM}} \\
(85 \mu \mathrm{m})\end{array}$ & $\begin{array}{l}\text { System } \\
\text { No. 2: } \\
\text { BioVision }^{\mathrm{TM}} \\
(50 \mu \mathrm{m})\end{array}$ & $\begin{array}{l}\text { System } \\
\text { No. 3: } \\
\text { Trident }^{\mathrm{TM}} \\
(70 \mu \mathrm{m})\end{array}$ & $\begin{array}{l}\text { System } \\
\text { No. 4: tomo- } \\
\text { synthesis } \\
(85 \mu \mathrm{m})\end{array}$ \\
\hline Radiologist 1 & 81.0 & 83.0 & 82.0 & 86.0 & 100.0 & 100.0 & 100.0 & 100.0 \\
\hline Radiologist 2 & 81.0 & 82.0 & 82.0 & 87.0 & 100.0 & 100.0 & 100.0 & 100.0 \\
\hline Radiologist 3 & 81.0 & 82.0 & 82.0 & 87.0 & 100.0 & 100.0 & 100.0 & 100.0 \\
\hline Mean & 81.0 & 82.3 & 82.0 & 86.6 & 100.0 & 100.0 & 100.0 & 100.0 \\
\hline $\begin{array}{l}\text { Magnification } \\
1.0: 1.8 \text { (No. 1) } \\
1.0: 2.0 \text { (No. 2) } \\
1.0: 2.0 \text { (No. } 3 \text { ) } \\
1.0: 1.0 \text { (No. } 4 \text { ) }\end{array}$ & $\begin{array}{l}\text { System } \\
\text { No. 1: } \\
\text { Inspira- } \\
\text { tion }^{\mathrm{TM}} \\
(85 \mu \mathrm{m})\end{array}$ & $\begin{array}{l}\text { System } \\
\text { No. 2: } \\
\text { BioVision }^{\mathrm{TM}} \\
(50 \mu \mathrm{m})\end{array}$ & $\begin{array}{l}\text { System } \\
\text { No. 3: } \\
\text { Trident }^{\mathrm{TM}} \\
(70 \mu \mathrm{m})\end{array}$ & $\begin{array}{l}\text { System } \\
\text { No. 4: tomo- } \\
\text { synthesis } \\
\text { (85 } \mu \mathrm{m})\end{array}$ & $\begin{array}{l}\text { System } \\
\text { No. 1: } \\
\text { Inspira- } \\
\text { tion }^{\mathrm{TM}} \\
(85 \mu \mathrm{m})\end{array}$ & $\begin{array}{l}\text { System } \\
\text { No. 2: } \\
\text { BioVision }^{\mathrm{TM}} \\
(50 \mu \mathrm{m})\end{array}$ & $\begin{array}{l}\text { System } \\
\text { No. 3: } \\
\text { Trident }^{\mathrm{TM}} \\
(70 \mu \mathrm{m})\end{array}$ & $\begin{array}{l}\text { System } \\
\text { No. 4: tomo- } \\
\text { synthesis } \\
(85 \mu \mathrm{m})\end{array}$ \\
\hline Radiologist 1 & 82.0 & 86.0 & 87.0 & 87.0 & 100.0 & 100.0 & 100.0 & 100.0 \\
\hline Radiologist 2 & 83.0 & 86.0 & 86.0 & 86.0 & 100.0 & 100.0 & 100.0 & 100.0 \\
\hline Radiologist 3 & 84.0 & 85.0 & 86.0 & 87.0 & 100.0 & 100.0 & 100.0 & 100.0 \\
\hline Mean & 83.0 & 85.6 & 86.3 & 86.6 & 100.0 & 100.0 & 100.0 & 100.0 \\
\hline
\end{tabular}




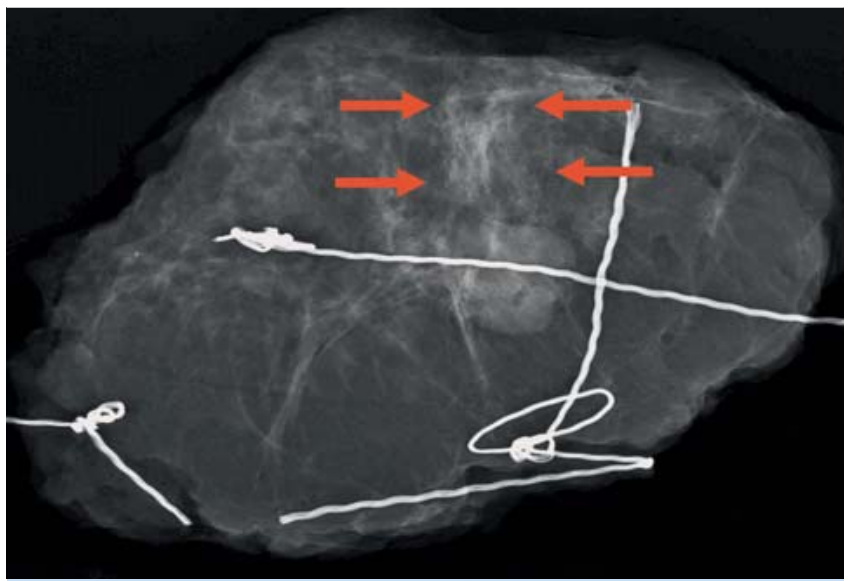

Fig. 1 Specimen radiograph. Inspiration ${ }^{\mathrm{TM}}$, magnification 1.0:2.0, invasive breast carcinoma PT1CNOM0, diameter $1.6 \mathrm{~cm}$; it is not possible to determine the length of the spicules (arrows) and differentiate them from surrounding tissue.

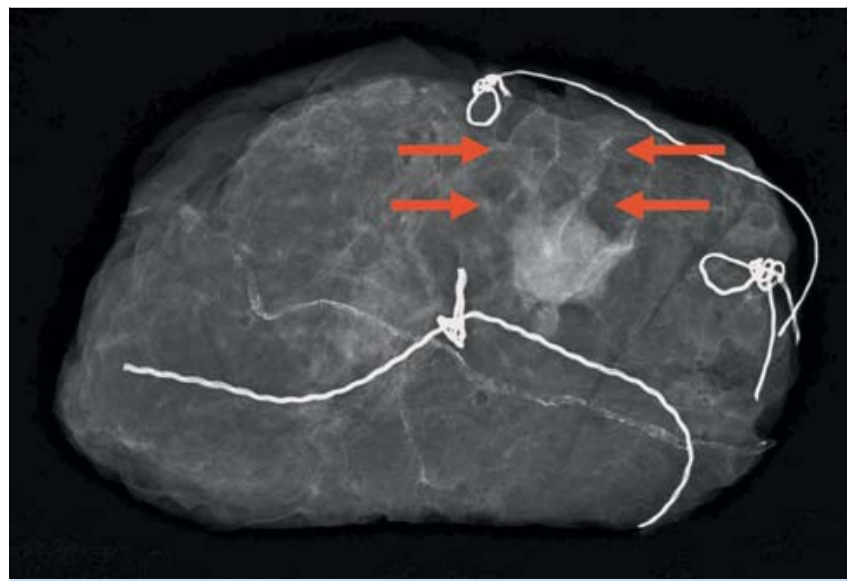

Fig. 2 BioVision $^{\mathrm{TM}}$ and Trident ${ }^{\mathrm{T} \mathrm{M}}$ : magnification 1.0:2,0, invasive breast carcinoma pT1cNOM0, diameter $1.6 \mathrm{~cm}$; the spicules (arrows) are clearly visible and easily differentiated from the surrounding tissue. Identical images were created when both systems (BioVision ${ }^{\mathrm{TM}}$ and Trident $\mathrm{t}^{\mathrm{TM}}$ ) were used under the same assessment conditions (expansion of the publication by Schulz-Wendtland R et al. Geburtsh Frauenheilk 2012; 72: 532-538).

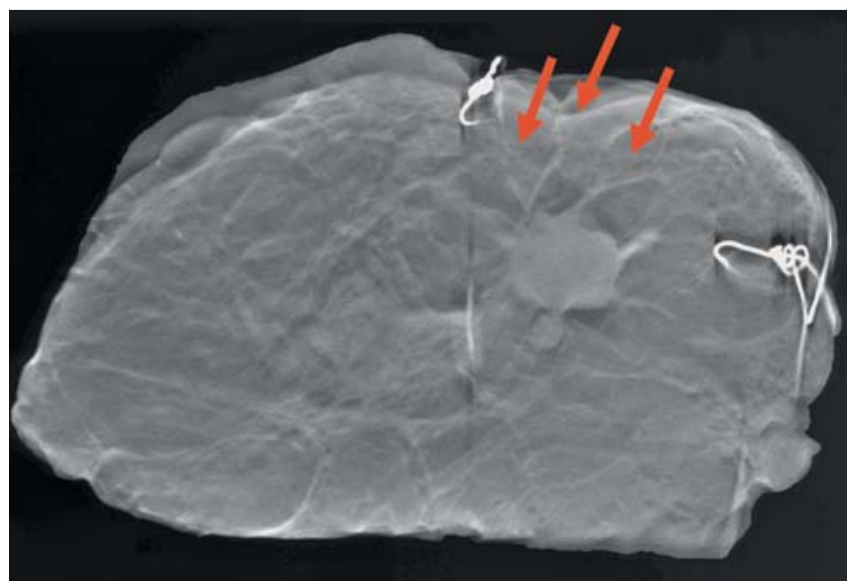

Fig. 3 Tomosynthesis, image 7 of 25 ; magnification $1.0 \times 1.0$, invasive breast carcinoma pT1cNOM0, diameter $1.6 \mathrm{~cm}$; the spicules (arrows) were clearly visible and could be differentiated well from the surrounding tissue (using imaging and confirmed by histological investigation). The guide wire was removed in $\odot$ Figs. 1 to 3 to show how the differentiation of the tumor from the surrounding tissue.

Table 3 Detailled representation of results (RO/R1) $(n=50)$ for the 4 diagnostic systems (System No. 1: Inspiration ${ }^{\mathrm{TM}}$, System No. 2: BioVision ${ }^{\mathrm{TM}}$, System No. 3: Trident ${ }^{\mathrm{TM}}$, System No. 4: tomosynthesis) at magnifications of 1.0:2.0 and $1.0: 1.0$ respectively (tomosynthesis), compared to the standard magnification of $1.0: 1.0$ and the final histological result.

\begin{tabular}{|c|c|}
\hline$n=50$ & \\
\hline $\begin{array}{l}\text { Histological diagnosis } \\
\text { R0: } n=39\end{array}$ & \\
\hline $\begin{array}{l}\text { Diagnosis with the Inspiration } \\
\text { R1: } n=11\end{array}$ & \\
\hline $\begin{array}{l}\text { Diagnosis with the BioVision }{ }^{\mathrm{TM}} \\
\text { R1: } n=9\end{array}$ & Histology \\
\hline $\begin{array}{l}\text { Diagnosis with the Trident }{ }^{\top \mathrm{M}} \\
\mathrm{R} 1: \mathrm{n}=8\end{array}$ & $\begin{array}{l}R 1: n=5 \\
R 0: n=6\end{array}$ \\
\hline $\begin{array}{l}\text { Diagnosis with tomosynthesis } \\
\text { R1: } n=7\end{array}$ & \\
\hline
\end{tabular}


Intraoperative imaging should be done on 2 planes, where possible, in accordance with the European Guidelines and the S3 Guidelines [8-11]. Radiography could be used to confirm the success of surgical resection intraoperatively. Direct imaging of the resected specimen in 2 planes would permit follow-up resection to be done immediately in cases of incomplete resection. The use of digital imaging plates in combination with conventional analog mammography systems represents a big step forward. These systems use CCD chips with their potential to transfer images to PACS, but the DQE (Detector Quantum Efficiency) is poorer compared to other full digital systems currently in use [14-22]. Over the past 10-15 years imaging systems used exclusively for specimen radiographs have been developed which can be used in different locations (operating room, radiology department, pathology department). Innovations in this field have included the move from conventional systems via the use of imaging plates and full digital systems [14-22] to CMOS technology [23] and tomosynthesis [24]. With the recent use of digital breast tomosynthesis (DBT) [25-32] to complement digital mammography specimen radiography can now be done intraoperatively. In the literature, it was noted that the increase in sensitivity and specificity obtained with tomosynthesis [28] used in addition to digital mammography could reduce recall rates [27,29], also in breast cancer screening of women [32]. In the system we used, specimens were examined radiologically using 25 projections and an angular range of 50 degrees.

Three radiologists assessed the specimen radiographs obtained with the BioVision $^{\mathrm{TM}}$ (CMOS technology, 2 planes, System 2), the Trident $^{\mathrm{TM}}$ (SRS technology, 2 planes, System 3) using different magnifications (up to $1.0: 2.0$ ) and tomosynthesis (1 plane, magnification $1.0: 1.0$, both projection images and cine mode images, System 4). Specimen radiographs obtained using the Inspiration $^{\mathrm{TM}}$ ( 2 planes, System 1 ) were defined as the standard; based on this standard re-excision was done in 11 of 50 patients with histologically proven breast cancer (BI-RADS ${ }^{\mathrm{TM}}$ 6) and primary breast-conserving therapy ( Table 1 ).

The BioVision (System 2) and Trident ${ }^{\mathrm{TM}}$ (System 3) systems are digital systems used exclusively for specimen radiography.

The final histopathological diagnosis of 11 operated patients (reexcision, 2-step procedure) showed that the primary operation was incomplete in 2 patients. However, only 3 patients had safety margins of $<1.0 \mathrm{~cm}$, i.e. with no residual tumor detectable. This means that, based on the final histopathological findings, re-excision was only justified in 5 patients.

A retrospective analysis $(n=11)$ showed a significant increase $(\mathrm{p}<0.05)$ in sensitivity for the BioVision ${ }^{\mathrm{TM}}$ and Trident ${ }^{\mathrm{TM}}$ systems and for tomosynthesis compared to the Inspiration ${ }^{\mathrm{TM}}$ at magnifications of $1.0: 2.0$ and $1.0: 1.0$ (tomosynthesis) respectively. Sensitivity increased by $2.6 \%, 3.3 \%$ and $3.6 \%$ respectively, i.e. re-excision would not have been necessary in 2, 3 and 4 patients respectively compared to images obtained using the standard magnification 1.0:1.0 ( Tables 2, 3) (๑ Figs. 1 to 3 ).

This may be due to the particularly high resolution of the BioVision $^{\mathrm{TM}}$ (focus 0.05 , resolution $50 \mu \mathrm{m}$ pixel pitch, $12 \mathrm{lp} / \mathrm{mm}$ ) and Trident $^{\mathrm{TM}}$ (focus 0.05 , resolution $70 \mu \mathrm{m}$ pixel pitch, $7.1 \mathrm{lp} / \mathrm{mm}$ ) systems, which were developed exclusively for specimen radiography, and to the principle behind tomosynthesis which allows the texture of breast parenchyma to be characterized very precisely in the mammogram (c - c and obliq.) [30] as is also evidenced in the specimen radiographs: differentiation is far better (spicules and extent of DCIS compared to benign ductal parenchyma).
In our historical patient cohort and our current retrospective analysis, the re-excision rate after primary breast-conserving therapy (BCT) to treat previously histologically verified breast carcinoma (histological diagnosis: B5 and therefore BI-RADS ${ }^{\mathrm{TM}} 6$ ) was $22 \%$; the rate in the literature is between 10 and $57 \%$, depending on the definition of the safety margin $[12,13]$. Our results thus correspond to, or exceed, those obtained using digital specimen radiography, even with the use of zooming [23,3337]. In conclusion, it should be noted that digital specimen radiography using a magnification of 1.0:2.0 and no zooming should be primarily done using systems developed exclusively for specimen radiography or tomosynthesis should be done [37]. Future developments which are expected to improve quality and reduce the rate of re-excisions include the use of 3-D technology in mammographies [38] and the potential use of volumetry based on tomosynthesis [31]. In future, specimen radiography in different planes could be done in the operating room and the images discussed immediately in consultation between the radiologist, surgeon, pathologist using PACS. If a tumorous lesion cannot be unambiguously differentiated from its surrounding tissue, further investigations in addition to ultrasound, for example tomosynthesis, are necessary. Images and findings are then recorded. This mode of procedure would improve the quality and workflows and simultaneously reduce operating times - to the benefit of the patients.

\section{Conflict of Interest}

$\nabla$

None.

\section{Affiliations}

' Gynäkologische Radiologie, Radiologisches Institut, Universitätsklinikum Erlangen, Erlangen

2 Radiologische Praxis Roth und Weißenburg, Roth

${ }^{3}$ Frauenklinik, Universitätsklinikum Erlangen, Erlangen

${ }^{4}$ Radiologisches Institut, Universitätsklinikum Erlangen, Erlangen

\section{References}

1 Ruckhaberle E, Solbach C, Kaufmann M. Conference report on the 31th annual San Antonio breast cancer symposium, December 10-14, 2008 "Continuing change in diagnostics and therapy of breast cancers - from molecular basics to tailored therapy". Geburtsh Frauenheilk 2009; 69: 202-211

2 Kaufmann M, Rody A. Breast cancer: reduced mortality by early detection and adjuvant therapy. Geburtsh Frauenheilk 2009; 69: 218-232

3 Katalinic A. Breast cancer: declining mortality despite its increasing incidence. Geburtsh Frauenheilk 2009; 69: 237-239

4 Beckmann MW, Blohmer JU, Costa SD et al. Zurich consensus: German expert opinion on the St. Gallen votes on 15 March 2009 (11th international conference at St. Gallen: primary therapy of early breast cancer). Geburtsh Frauenheilk 2009; 69: 377-383

5 Ruckhaberle E, Rody A, Kaufmann M. Report of the 32nd annual St. Antonio breast cancer symposium, December 10-13, 2009 "An international scientific symposium for interaction and exchange among basic scientists and clinicians in breast cancer". Geburtsh Frauenheilk 2010; 70: 177-183

6 Fasching PA, Fehm T, Janni Wet al. Breast cancer therapy - a state of the art review. Geburtsh Frauenheilk 2010; 70: 875-886

7 Fasching PA, Ekici AB, Adamietz BR et al. Breast cancer risk - genes, environment and clinics. Geburtsh Frauenheilk 2011; 71: 1056-1066

8 Perry NM. Quality assurance in the diagnosis of breast disease. Eur J Cancer 2001; 37: 159-172

9 Wallis M, Tardivon A, Helbich T et al. Guidelines from the European Society of Breast Imaging for diagnostic interventional breast procedures. Eur Radiol 2007; 17: 581-588 
10 Albert US, Hrsg. S3-Leitlinie Brustkrebs-Früherkennung in Deutschland. Aktualisierung 2012. München: W. Zuckschwerdt-Verlag; 2012; www.senologie.org; last access: Juli 2012

11 Kreienberg R, Kopp I, Albert US et al. S3-Leitlinie Diagnostik, Therapie und Nachsorge des Mammakarzinoms. 1. Aktualisierung. München: W. Zuckschwerdt-Verlag; 2008; www.senologie.org; last access: Juli 2008

12 Bani MR, Lux MP, Heusinger $K$ et al. Factors correlating with reexcision after breast-conserving therapy. EJSO 2009; 35: 32-37

13 D'Orsi CJ. Management of the breast specimen. Radiology 1995; 194: 297-302

14 Grunert J-H, Wiechmann U, Gmelin E. Kompressionsfreie Mammapräparateradiographie in 2 Ebenen mit Hilfe eines Radiographiecontainers. Fortschr Röntgenstr 2003; 175: 413-417

15 Kürzl R, Baltzer J, Lohe KJ. Intraoperative specimen radiography in mammographically suspected, non palpable breast lesions. Experiences with the Faxitron unit. Fortschr Med 1979; 97: 1688-1690

16 Kürzl R, Lohe KJ, Baltzer J et al. Radiography used during operations for biopsies of non-palpable lesions of the breast which have been suspected because of mammography. J Gynecol Obstet Biol Reprod 1981; 10: $431-434$

17 Moritz JD, Westerhof JP, Funke $M$ et al. Ein neues Präparatradiographiegerät mit maximal 20facher Vergrößerung für die Mammadiagnostik. Fortschr Röntgenstr 1998; 168: 133-138

18 Grunert JH, Borchert B, Farber A et al. Mikrokalknachweis in MammaExzisionspräparaten mit Hilfe der DIMA-Vergrößerungspräparateradiographie vierfach im Vergleich zur konventionellen Vergrößerungsradiographie eineinhalbfach. Fortschr Röntgenstr 1999; 171: 302-306

19 Grunert J-H, Flemming $P$, Borchert $B$ et al. Vergrößerungspräparateradiographie als Qualitätskontrolle der Mikrokalkerfassung im Rahmen der histopathologischen Aufarbeitung von Mammabiopsiegewebe. Fortschr Röntgenstr 2000; 172: 68-72

20 Diekmann F, Grebe S, Bick U et al. Digitale intraoperative Präparateradiographie bei diagnostischen Exzisionen nicht palpabler Läsionen der Brust. Fortschr Röntgenstr 2000; 172: 969-971

21 Muttalib M, Tisdall M, Scawn R et al. Intra-operative specimen analysis using faxitron microradiography for excision of mammographically suspicious, non-palpable breast lesions. The Breast 2004; 13: 307-315

22 Schulz-Wendtland R, Wenkel E, Wacker T et al. Quo vadis? Trends in digital mammography. Geburtsh Frauenheilk 2009; 69: 108-117

23 Schulz-Wendtland R, Bani MR, Lux MP et al. CMOS-Technologie für intraoperative digitale Präparateradiografien. Geburtsh Frauenheilk 2011: 71: 525-529

24 Schulz-Wendtland R, Dilbat G, Bani MR et al. Use of tomosynthesis in intraoperative digital specimen radiography - is a reduction of breast reexcision rates possible? Geburtsh Frauenheilk 2011; 71: 1080-1084
25 Niklason LT, Christian BT, Niklason LE et al. Digital tomosynthesis in breast imaging. Radiology 1997; 205: 399-406

26 Schulz-Wendtland $R$, Wenkel, E. Experimental phantom lesion detectability study using a digital breast tomosynthesis prototype system. Röfo 2006; 178: 1219-1223

27 Poplack SP, Tosteson TD, Kogel CA et al. Digital breast tomosynthesis: initial experience in 98 women with abnormal digital screening mammography. AJR 2007; 189: 616-623

28 Good WF, Abrams GS, Catullo VJ et al. Digital breast tomosynthesis: a pilot observer study. AJR 2008; 190: 865-869

29 Gur D, Abrams GS, Chough DM et al. Digital breast tomosynthesis: observer performance study. AJR 2009; 193: 586-591

30 Kontos D, Bakic PR, Carton AK et al. Parenchymal texture analysis in digital breast tomosynthesis for breast cancer risk estimation: a preliminary study. Acad Radiol 2009; 16: 283-298

31 Schulz-Wendtland R, Fuchsjäger M, Wacker T et al. Digital mammography: an update. Eur J Radiol 2009; 72: 258-265

32 Teertstra HJ, Loo CE, van den Bosch MA et al. Breast tomosynthesis in clinical practice: initial results. Eur Radiol 2010; 20: 16-24

33 Schulz-Wendtland R, Hermann K-P, Wenkel E et al. Vergleich der klinischen Wertigkeit von Zielaufnahmen mit reduzierter Pixelgröße des Detektors und digitalem Monitorzooming bei der Beurteilung von Mikrokalzifikationen in der digitalen Mammographie. Fortschr Röntgenstr 2007; 179: 492-496

34 Haygood TM, Arribas E, Brennan PC et al. Conspicuity of microcalcifications on digital screening mammograms using varying degrees of monitor zooming. Acad Radiol 2009; 16: 1509-1517

$35 \mathrm{Kim}$ MJ, Youk JH, Kang DR et al. Zooming method (x 2.0) of digital mammography vs. digital magnification view (x 1.8) in full-field digital mammography for the diagnosis of microcalcifications. Br J Radiol 2010; 83: 486-492

36 Koutalonis M, Delis H, Pascoal A et al. Can electronic zoom replace magnification in mammography? BJR 2010; 83: 569-577

37 Schulz-Wendtland $R$, Dilbat G, Bani $M$ et al. Full field mammography (FFDM) versus CMOS technology versus tomosynthesis (DBT) - which system increases the quality of intraoperative imaging? Geburtsh Frauenheilk 2012; 72: 532-538

38 Schulz-Wendtland R, Bani MR, Lux MP et al. Pilot study on the detection of simulated lesions using a 2D and 3D digital full-field mammography system with a newly developed high resolution detector based on two shifts of a-Se. Geburtsh Frauenheilk 2012; 72: 408-411

Deutschsprachige Zusatzinformationen online abrufbar unter: www.thieme-connect.de/ejournals/toc/gebfra. 